\title{
Assemblages of peracarid crustaceans in subtidal sediments from the Ría de Aldán (Galicia, NW Spain)
}

\author{
Antía Lourido · Juan Moreira · Jesús S. Troncoso
}

Received: 7 February 2008 / Revised: 26 February 2008 / Accepted: 6 March 2008 / Published online: 16 May 2008

(C) Springer-Verlag and AWI 2008

\begin{abstract}
Peracarid crustaceans inhabit many marine benthic habitats and are good indicators of environmental conditions. There is, however, a lack of information about diversity and distribution of peracarid crustaceans on the shallow subtidal sediments of the Galician rias. In the summer of 1997, 27 subtidal stations were sampled in the Ría de Aldán, a ria on the southern margin of the mouth of the Ría de Pontevedra (Galicia, NW Spain). A total of 16,191 peracarid individuals were collected, comprising 125 species belonging to five orders. Amphipods were dominant in number of species and individuals, followed by isopods and cumaceans. Multivariate analyses of these data indicated that depth and sediment granulometry were major determinants of distribution and composition of peracarid assemblages in the ria.
\end{abstract}

Keywords Peracarida - Soft-bottoms · Assemblages ·

Atlantic Ocean · Ría de Aldán

\section{Introduction}

Peracarid crustaceans are among the most diverse and numerically dominant organisms of soft-bottom benthic

Communicated by H.-D. Franke.

A. Lourido $(\varangle) \cdot$ J. S. Troncoso

Departamento de Ecoloxía e Bioloxía Animal,

Facultade de Ciencias del Mar,

Campus de Lagoas-Marcosende s/n,

Universidade de Vigo, 36310 Vigo, Spain

e-mail: antial@uvigo.es

J. Moreira

Estación de Bioloxía Mariña da Graña,

Universidade de Santiago de Compostela,

Casa do Hórreo, Rúa da Ribeira 1,

15590 A Graña, Ferrol, Spain faunas (Fincham 1974; Dauvin et al. 1994; Prato and Biandiolino 2005). Peracarids also play an important role in structuring of benthic assemblages (Duffy and Hay 2000) and are important source of food for other benthic animals and fishes of commercial importance (McDermott 1987; Dauvin 1988a; Beare and Moore 1996). Distribution and abundance of peracarids inhabiting marine sediments are influenced by a number of abiotic factors, such as sediment composition (Parker 1984; De Grave 1999) and organic content (Robertson et al. 1989). Many peracarid species are also sensitive to hydrocarbon pollution and other perturbations and, therefore, their abundance and species diversity may serve as indicators of environmental conditions (e.g., Marques and Bellan-Santini 1990; Corbera and Cardell 1995; Gómez-Gesteira and Dauvin 2000; Guerra-García and García-Gómez 2004).

The Galician rias (NW Spain) are a special and complex kind of estuarine system and have a great economic and social importance due to the presence of fisheries, bivalve culture and shellfish resources (Nombela et al. 1995; Figueiras et al. 2002). The rias also have a large diversity of sedimentary habitats inhabited by a particularly rich benthic fauna (Cadée 1968; López-Jamar and Mejuto 1985). Peracarid fauna of the Galician rias, however, are little known and few studies have been devoted to describe diversity, distribution and composition of peracarid assemblages on their soft-bottoms (Anadón 1975; Sánchez-Mata et al. 1993).

Composition and distribution of soft-bottom benthos are well-known in many areas of the Galician coast (Viéitez and Baz 1988; Junoy and Viéitez 1989; Mazé et al. 1990; Palacio et al. 1991; Currás and Mora 1991). There is, however, a lack of studies in some small rias such as the Ría de Aldán. This ría is located on the mouth of the Ría de Pontevedra and shows a variety of subtidal sediments, ranging 
from gravel to mud, at depths of between 3 and $45 \mathrm{~m}$. Thus, the main objectives of this paper were to characterize the composition and distribution of the peracarid fauna on the subtidal soft-bottoms of the Ría de Aldán as well as studying the influence of several environmental variables on the distribution patterns of peracarids. This will also provide baseline data for further comparative analyses.

\section{Material and methods}

\section{Study area}

The Ría de Aldán is situated on the southern margin of the mouth of Ría de Pontevedra, between $42^{\circ} 16^{\prime} 40^{\prime \prime}$ $42^{\circ} 20^{\prime} 50^{\prime \prime} \mathrm{N}$ and $8^{\circ} 49^{\prime}-8^{\circ} 52^{\prime} \mathrm{W}$. This ria has $7 \mathrm{~km}$ length, $3.5 \mathrm{~km}$ width and has a maximum depth of $45 \mathrm{~m}$; its mouth is oriented northwards. Mean salinity values are around $36 \%$ in outer areas of the ria and there is gradual increase in salinity from the inner to the outer part of the ria (Parada 2004). The small Aldán River flows into the inner area. Both East and West margins are made up of rocky substratum which alternates with sandy beaches. The ria is greatly influenced by strong oceanic hydrodynamism which reaches the inner areas and reduces the effect of freshwater input from the Aldán River. The ria is influenced by the growing practice of bivalve culture on rafts, mostly in the inner areas of the ria; these practices are supposed to contribute to the increase of the content of silt/clay and organic matter in those areas, such as it occurs in other Galician rías.

Sample collection and processing

The sampling programme comprised 27 stations which covered the full extent of the ria in order to provide sufficient information on the distribution of peracarids (Fig. 1; Table 1). Quantitative sampling was done during JulyAugust 1997 using a Van Veen grab with a sampling area of $0.056 \mathrm{~m}^{2}$. Five replicates were taken at each station, which accounted for a total area of $0.28 \mathrm{~m}^{2}$. Samples were sieved through a $0.5 \mathrm{~mm}$ mesh, and fixed in $10 \%$ buffered formaldehyde solution for later sorting and identification of the fauna. An additional sediment sample was taken at each station to analyse granulometric composition, carbonates and organic matter content. The following granulometric fractions were considered: gravel (GR $>2 \mathrm{~mm}$ ), very coarse sand (VCS 1-2 mm), coarse sand (CS 0.5-1 mm), medium sand (MS 0.25-0.5 mm), fine sand (FS $0.125-0.25 \mathrm{~mm}$ ), very fine sand (VFS $0.063-0.125 \mathrm{~mm}$ ), and silt/clay $(<0.063 \mathrm{~mm})$. Median grain size $\left(\mathrm{Q}_{50}\right)$ and sort coefficient $\left(S_{0}\right)$ (Trask 1932) were also determined for each sample. Temperature was also measured in sediment, surface water and bottom water. Sediment types were characterized according to Junoy (1996). Calcium carbonate content (\%) was estimated by the treatment of the sample with hydrochloric acid. The total organic matter content (TOM, \%) was estimated from the weight loss after placing samples in a furnace for $4 \mathrm{~h}$ at $450^{\circ} \mathrm{C}$.

Data analysis

Several univariate measures were calculated for each sampling station: total abundance $(N)$, number of species $(S)$, the Shannon-Wiener diversity index $\left(\mathrm{H}^{\prime}\right.$, as $\left.\log _{2}\right)$, and Pielou's evenness (J). For any given site, species with $\geq 4 \%$ of total abundance were considered as dominant (Field et al. 1982). Peracarid assemblages were determined through non-parametric multivariate techniques as described by Field et al. (1982) using the PRIMER v5.0 (Plymouth Routines in Multivariate Ecological Research) software package (Clarke and Warwick 1994). A similarity matrix was constructed by means of the Bray-Curtis similarity coefficient by first applying fourth root transformation on species abundance to minimise the contribution of the most abundant species. Differences in faunistic composition between sampling stations were tested using the one-way ANOSIM test. From the similarity matrix, classification of stations was done by cluster analysis based on the group-average sorting algorithm and an ordination by means of non-metric multidimensional scaling (nMDS). The SIMPER program was next used to identify species that greatly contributed to the differentiation of station groups. The species present in each group of stations were further classified according to the constancy and fidelity indexes (Glémarec 1964; Cabioch 1968).

The BIO-ENV procedure (belonging to the PRIMER package), and the canonical correspondence analysis (CCA, using the CANOCO v4.02, Canonical Community Ordination package; Ter Braak 1988) were used to research the possible relationship between peracarid distribution in the ria, and the measured environmental variables. The forward selection was used in the latter to detect which variables explained the most variance in the species data. All variables expressed in percentages were previously transformed by $\log (x+1)$.

\section{Results}

\section{Sediments}

Sediments were mainly sandy in most of the ria (Fig. 1; Table 1). Coarser sandy granulometric fractions were more prevalent at the mouth of the ria, and muddy bottoms were restricted to inner and sheltered areas. There was a decrease 
Fig. 1 a Location of the Ría de Aldán, b location of sampling stations and spatial distribution of peracarid assemblages in the ria as determined by multivariate analyses and $\mathbf{c}$ bathymetry $(\mathrm{m})$ in numbers and sediment type in the ria

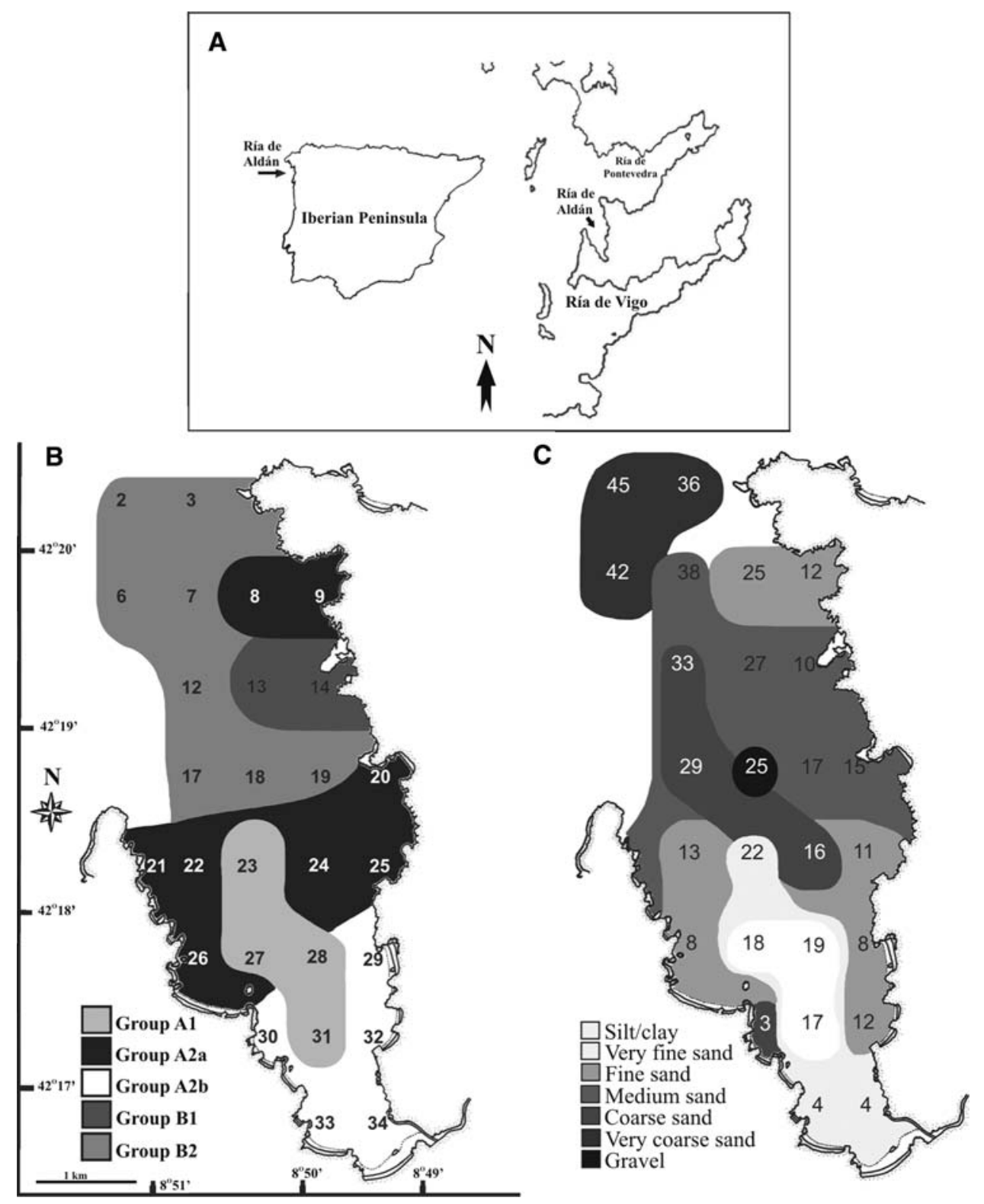

in grain size and an increase in organic content from the outer areas to the inner areas of the ria.

\section{Peracarid fauna}

A total of 16,191 peracarid individuals were collected, comprising 125 species of peracarids belonging to five orders. Amphipods were the best represented in total number of species (79) and individuals $(73.4 \%$ of numerical abundance) followed by isopods (20 species and $2.6 \%$ abundance) and cumaceans (14 species and 2.7\% abundance). Tanaids and mysids were less diverse in number of species ( 5 and 7 , respectively). Tanaids comprised $20.6 \%$ of the total abundance, mostly due to the abundance of Apseudes latreillii (Milne-Edwards, 1828) in some sites.
Values of univariate measures are shown in Table 2. The lowest abundance values were recorded at medium sand (St. 13, 171 individuals $/ \mathrm{m}^{2}$ ), while the highest numbers were recorded at muddy sand (St. 34, 12,229 individuals/ $\mathrm{m}^{2}$ ). Number of species varied between 15 (St. 13) and 38 (St. 29, fine sand); diversity ranged from 0.79 (St. 21, medium sand) and 4.26 (St. 32, fine sand). Evenness showed low values on sediments with a high dominance of Siphonoecetes kroyeranus Bate, 1856 (St. 21; J, 0.18), Apseudes latreilli (St. 22, 24, 34; J, 0.30-0.52) and Gammarella fucicola (Leach, 1814) (St. 33; J, 0.44).

The dominant species in terms of abundance were the tanaid Apseudes latreillii and the amphipods Siphonoecetes kroyeranus, Photis longipes (della Valle, 1893), Gammarella fucicola, Aoridae spp. (undetermined females), 
Table 1 Position, depth, sediment and water temperature and sedimentary characteristics of sampling stations in the Ría de Aldán

\begin{tabular}{|c|c|c|c|c|c|c|c|c|c|c|c|c|c|}
\hline Station & Position & $\begin{array}{l}\text { Depth } \\
\text { (m) }\end{array}$ & $\begin{array}{l}\text { Surf } \\
\text { temp } \\
\left({ }^{\circ} \mathrm{C}\right)\end{array}$ & $\begin{array}{l}\text { Bottom } \\
\text { temp } \\
\left({ }^{\circ} \mathrm{C}\right)\end{array}$ & $\begin{array}{l}\text { Sed } \\
\text { temp } \\
\left({ }^{\circ} \mathrm{C}\right)\end{array}$ & $\begin{array}{l}\text { Gravel } \\
(\%)\end{array}$ & $\begin{array}{l}\text { Sand } \\
(\%)\end{array}$ & $\begin{array}{l}\text { Silt/clay } \\
(\%)\end{array}$ & $\begin{array}{l}\mathrm{Q}_{50} \\
(\mathrm{~mm})\end{array}$ & Sediment type & $\mathrm{S}_{0}$ & $\begin{array}{l}\text { Carbonates } \\
(\%)\end{array}$ & $\begin{array}{l}\text { TOM } \\
(\%)\end{array}$ \\
\hline 2 & $42^{\circ} 20^{\prime} 15^{\prime \prime} \mathrm{N}, 8^{\circ} 51^{\prime} 15^{\prime \prime} \mathrm{W}$ & 45 & 21.1 & 22.9 & 20.0 & 10.0 & 88.0 & 2.0 & 1.079 & $\begin{array}{l}\text { Very coarse } \\
\text { sand }\end{array}$ & Moderate & 73.9 & 2.6 \\
\hline 3 & $42^{\circ} 20^{\prime} 15^{\prime \prime} \mathrm{N}, 8^{\circ} 50^{\prime} 45^{\prime \prime} \mathrm{W}$ & 36 & 21.4 & 22.3 & 20.8 & 47.9 & 49.0 & 3.2 & 1.983 & $\begin{array}{l}\text { Very coarse } \\
\text { sand }\end{array}$ & Moderate & 89.8 & 2.6 \\
\hline 6 & $42^{\circ} 19^{\prime} 45^{\prime \prime} \mathrm{N}, 8^{\circ} 51^{\prime} 15^{\prime \prime} \mathrm{W}$ & 42 & 18.5 & 18.4 & 18.2 & 27.1 & 70.7 & 2.2 & 1.053 & $\begin{array}{l}\text { Very coarse } \\
\text { sand }\end{array}$ & Poor & 32.3 & 1.0 \\
\hline 7 & $42^{\circ} 19^{\prime} 45^{\prime \prime} \mathrm{N}, 8^{\circ} 50^{\prime} 45^{\prime \prime} \mathrm{W}$ & 38 & 17.0 & 17.7 & 17.4 & 0.3 & 97.4 & 2.4 & 0.485 & Medium sand & Moderate & 67.4 & 1.4 \\
\hline 8 & $42^{\circ} 19^{\prime} 45^{\prime \prime} \mathrm{N}, 8^{\circ} 50^{\prime} 15^{\prime \prime} \mathrm{W}$ & 25 & 22.1 & 21.4 & 19.6 & 0.1 & 97.0 & 2.9 & 0.211 & Fine sand & $\begin{array}{c}\text { Mod. well } \\
\text { sorted }\end{array}$ & 52.7 & 1.3 \\
\hline 9 & $42^{\circ} 19^{\prime} 45^{\prime \prime} \mathrm{N}, 8^{\circ} 49^{\prime} 45^{\prime \prime} \mathrm{W}$ & 12 & 18.7 & 18.6 & 17.9 & 0.2 & 96.8 & 3.0 & 0.202 & Fine sand & $\begin{array}{c}\text { Mod. well } \\
\text { sorted }\end{array}$ & 67.9 & 2.0 \\
\hline 12 & $42^{\circ} 19^{\prime} 15^{\prime \prime} \mathrm{N}, 8^{\circ} 50^{\prime} 45^{\prime \prime} \mathrm{W}$ & 33 & 18.1 & 18.6 & 17.2 & 18.4 & 79.5 & 2.1 & 0.869 & Coarse sand & Moderate & 38.2 & 0.7 \\
\hline 13 & $42^{\circ} 19^{\prime} 15^{\prime \prime} \mathrm{N}, 8^{\circ} 50^{\prime} 15^{\prime \prime} \mathrm{W}$ & 27 & 16.8 & 16.7 & 16.6 & 0.3 & 98.0 & 1.6 & 0.383 & Medium sand & Moderate & 40.8 & 1.1 \\
\hline 14 & $42^{\circ} 19^{\prime} 15^{\prime} \mathrm{N}, 8^{\circ} 49^{\prime} 45^{\prime \prime} \mathrm{W}$ & 10 & 17.3 & 17.4 & 17.0 & 0.8 & 96.5 & 2.8 & 0.391 & Medium sand & Moderate & 57.0 & 1.3 \\
\hline 17 & $42^{\circ} 18^{\prime} 45^{\prime \prime} \mathrm{N}, 8^{\circ} 50^{\prime} 45^{\prime \prime} \mathrm{W}$ & 29 & 19.9 & 21.2 & 20.2 & 13.5 & 84.2 & 1.8 & 0.623 & Coarse sand & Moderate & 32.6 & 0.5 \\
\hline 18 & $42^{\circ} 18^{\prime} 45^{\prime \prime} \mathrm{N}, 8^{\circ} 50^{\prime} 15^{\prime \prime} \mathrm{W}$ & 25 & 18.4 & 18.3 & 17.7 & 52.7 & 44.8 & 2.5 & 2.224 & Gravel & Moderate & 33.0 & 2.0 \\
\hline 19 & $42^{\circ} 18^{\prime} 45^{\prime \prime} \mathrm{N}, 8^{\circ} 49^{\prime} 45^{\prime \prime} \mathrm{W}$ & 17 & 18.4 & 18.1 & 17.1 & 0.5 & 96.1 & 3.4 & 0.331 & Medium sand & Moderate & 64.1 & 1.7 \\
\hline 20 & $42^{\circ} 18^{\prime} 45^{\prime \prime} \mathrm{N}, 8^{\circ} 49^{\prime} 15^{\prime \prime} \mathrm{W}$ & 15 & 18.7 & 18.7 & 17.6 & 0.8 & 95.3 & 3.9 & 0.300 & Medium sand & Moderate & 55.9 & 2.0 \\
\hline 21 & $42^{\circ} 18^{\prime} 22^{\prime \prime} \mathrm{N}, 8^{\circ} 51^{\prime} 05^{\prime \prime} \mathrm{W}$ & 4 & 21.1 & 20.8 & 20.2 & 2.3 & 93.2 & 4.5 & 0.290 & Medium sand & Moderate & 70.0 & 3.1 \\
\hline 22 & $42^{\circ} 18^{\prime} 15^{\prime \prime} \mathrm{N}, 8^{\circ} 50^{\prime} 45^{\prime} \mathrm{W}$ & 13 & 21.2 & 21.2 & 20.6 & 1.1 & 95.5 & 3.4 & 0.199 & Fine sand & $\begin{array}{c}\text { Mod. well } \\
\text { sorted }\end{array}$ & 55.2 & 1.9 \\
\hline 23 & $42^{\circ} 18^{\prime} 15^{\prime \prime} \mathrm{N}, 8^{\circ} 50^{\prime} 15^{\prime \prime} \mathrm{W}$ & 22 & 22.7 & 23.3 & 23.0 & 0.2 & 94.5 & 5.3 & 0.203 & Muddy sand & $\begin{array}{l}\text { Mod. well } \\
\text { sorted }\end{array}$ & 60.3 & 3.2 \\
\hline 24 & $42^{\circ} 18^{\prime} 15^{\prime \prime} \mathrm{N}, 8^{\circ} 49^{\prime} 45^{\prime \prime} \mathrm{W}$ & 16 & 20.6 & 21.4 & 21.4 & 21.6 & 74.2 & 4.2 & 0.919 & Coarse sand & Moderate & 65.5 & 2.5 \\
\hline 25 & $42^{\circ} 18^{\prime} 15^{\prime} \mathrm{N}, 8^{\circ} 49^{\prime} 15^{\prime \prime} \mathrm{W}$ & 11 & 21.2 & 21.5 & 21.6 & 0.1 & 96.7 & 3.2 & 0.192 & Fine sand & $\begin{array}{c}\text { Mod. well } \\
\text { sorted }\end{array}$ & 54.2 & 1.6 \\
\hline 26 & $42^{\circ} 17^{\prime} 45^{\prime \prime} \mathrm{N}, 8^{\circ} 50^{\prime} 45^{\prime \prime} \mathrm{W}$ & 8 & 21.4 & 21.2 & 21.7 & 0.7 & 92.7 & 6.6 & 0.142 & Fine sand & Moderate & 59.4 & 2.3 \\
\hline 27 & $42^{\circ} 17^{\prime} 45^{\prime \prime} \mathrm{N}, 8^{\circ} 50^{\prime} 15^{\prime \prime} \mathrm{W}$ & 18 & 17.1 & 17.3 & 17.3 & 6.0 & 34.8 & 59.2 & 0.050 & Mud & Poor & 33.8 & 9.0 \\
\hline 28 & $42^{\circ} 17^{\prime} 45^{\prime \prime} \mathrm{N}, 8^{\circ} 49^{\prime} 45^{\prime \prime} \mathrm{W}$ & 19 & 18.7 & 18.2 & 17.6 & 8.9 & 31.3 & 59.8 & 0.050 & Mud & Poor & 37.8 & 8.8 \\
\hline 29 & $42^{\circ} 17^{\prime} 45^{\prime \prime} \mathrm{N}, 84^{\circ} 9^{\prime} 15^{\prime \prime} \mathrm{W}$ & 8 & 17.9 & 18.2 & 18.2 & 8.8 & 87.2 & 4.0 & 0.210 & Fine sand & Moderate & 59.9 & 2.2 \\
\hline 30 & $42^{\circ} 17^{\prime} 15 \mathrm{~N}, 8^{\circ} 50^{\prime} 15^{\prime \prime} \mathrm{W}$ & 3 & 21.6 & 21.5 & 23.5 & 5.8 & 92.9 & 1.4 & 0.868 & Coarse sand & $\begin{array}{c}\text { Mod. well } \\
\text { sorted }\end{array}$ & 41.9 & 0.7 \\
\hline 31 & $42^{\circ} 17^{\prime} 15^{\prime} \mathrm{N}, 8^{\circ} 49^{\prime} 45^{\prime \prime} \mathrm{W}$ & 17 & 22.5 & 22.5 & 19.5 & 4.1 & 26.6 & 69.4 & 0.040 & Mud & Moderate & 40.3 & 10.8 \\
\hline 32 & $42^{\circ} 17^{\prime} 22^{\prime \prime} \mathrm{N}, 8^{\circ} 49^{\prime} 22^{\prime \prime} \mathrm{W}$ & 12 & 17.5 & 18.7 & 18.4 & 3.9 & 93.6 & 2.5 & 0.195 & Fine sand & $\begin{array}{c}\text { Mod. well } \\
\text { sorted }\end{array}$ & 63.0 & 1.5 \\
\hline 33 & $42^{\circ} 16^{\prime} 45^{\prime \prime} \mathrm{N}, 8^{\circ} 49^{\prime} 45^{\prime \prime} \mathrm{W}$ & 4 & 21.0 & 21.9 & 27.3 & 29.8 & 56.5 & 13.3 & 0.230 & Muddy sand & Bad & 38.8 & 5.0 \\
\hline 34 & $42^{\circ} 16^{\prime} 40^{\prime \prime} \mathrm{N}, 8^{\circ} 49^{\prime} 22^{\prime \prime} \mathrm{W}$ & 4 & 21.3 & 22.9 & 21.2 & 8.1 & 86.4 & 5.6 & 0.317 & Muddy sand & Poor & 33.5 & 1.1 \\
\hline
\end{tabular}

Bottom temp bottom water temperature, surf temp surface water temperature, sed temp sediment temperature, $Q_{50}$ median grain size, $S_{0}$ sorting coefficient, TOM total organic matter

Microdeutopus versiculatus (Bate, 1856), Guernea coalita (Norman, 1868), Perioculodes longimanus (Bate and Westwood, 1868), Leucothoe incisa Robertson, 1892, Ampithoe ramondi Audouin, 1826 and Ampelisca typica (Bate, 1856), and the cumacean Cumella sp. The remaining peracarid taxa comprised less than $25 \%$ of the total abundance.

The most widespread species in the ria (at least found in 15 sampling sites) were the amphipods Leucothoe incisa, Aoridae spp., Perioculodes longimanus, Photis longipes and Atylus vedlomensis (Bate and Westwood, 1862), the isopods Eurydice truncata (Norman, 1868) and Campeco- pea hirsuta (Montagu, 1804), and the cumacean Cumella sp. (Table 3). About $55 \%$ of the species were only found in one to four sites.

Multivariate analyses

The ANOSIM test revealed significant differences in faunistic composition between all stations (global $R, 0.865$; $P, 0.001)$, except between St. 2 and $17(R, 0.148 ; P, 0.14)$, St. 17 and $19(R, 0.108 ; P, 0.21)$, and St. 24 and $26(R$, $0.172 ; P, 0.05)$. The dendrogram obtained by cluster anal- 
Table 2 Number of species $(S)$, total abundance per $\mathrm{m}^{2}$ and $0.28 \mathrm{~m}^{2}$ $(N)$, Shannon Wiener's diversity index $\left(\mathrm{H}^{\prime}, \log _{2}\right)$ and Pielou's evenness $(J)$ for each sampling station in the Ría de Aldán

\begin{tabular}{|c|c|c|c|c|c|c|}
\hline Station & Group & $S$ & $N\left(\mathrm{~m}^{2}\right)$ & $N\left(0.28 \mathrm{~m}^{2}\right)$ & $\mathrm{H}^{\prime}$ & $J$ \\
\hline 2 & B2 & 17 & 336 & 94 & 3.11 & 0.76 \\
\hline 3 & B2 & 29 & 750 & 210 & 3.90 & 0.80 \\
\hline 6 & B2 & 16 & 275 & 77 & 3.54 & 0.88 \\
\hline 7 & B2 & 21 & 443 & 124 & 3.59 & 0.82 \\
\hline 8 & $\mathrm{~A} 2 \mathrm{a}$ & 16 & 243 & 68 & 3.42 & 0.85 \\
\hline 9 & $\mathrm{~A} 2 \mathrm{a}$ & 18 & 629 & 176 & 3.56 & 0.85 \\
\hline 12 & B2 & 29 & 796 & 223 & 3.88 & 0.80 \\
\hline 13 & B1 & 15 & 171 & 48 & 3.21 & 0.82 \\
\hline 14 & B1 & 16 & 436 & 122 & 2.33 & 0.58 \\
\hline 17 & B2 & 18 & 361 & 101 & 3.18 & 0.76 \\
\hline 18 & B2 & 33 & 3,071 & 860 & 3.47 & 0.69 \\
\hline 19 & B2 & 25 & 286 & 80 & 3.78 & 0.81 \\
\hline 20 & $\mathrm{~A} 2 \mathrm{a}$ & 26 & 1,132 & 317 & 3.35 & 0.71 \\
\hline 21 & $\mathrm{~A} 2 \mathrm{a}$ & 23 & 9,464 & 2,650 & 0.79 & 0.18 \\
\hline 22 & $\mathrm{~A} 2 \mathrm{a}$ & 19 & 2,693 & 754 & 1.43 & 0.34 \\
\hline 23 & A1 & 20 & 361 & 101 & 3.68 & 0.85 \\
\hline 24 & $\mathrm{~A} 2 \mathrm{a}$ & 29 & 2,814 & 788 & 1.46 & 0.30 \\
\hline 25 & $\mathrm{~A} 2 \mathrm{a}$ & 26 & 671 & 188 & 3.96 & 0.84 \\
\hline 26 & $\mathrm{~A} 2 \mathrm{a}$ & 29 & 1,386 & 388 & 3.68 & 0.76 \\
\hline 27 & A1 & 21 & 686 & 192 & 3.74 & 0.85 \\
\hline 28 & $\mathrm{~A} 1$ & 30 & 1,025 & 287 & 3.85 & 0.79 \\
\hline 29 & $\mathrm{~A} 2 \mathrm{~b}$ & 38 & 5,389 & 1,509 & 3.20 & 0.61 \\
\hline 30 & $\mathrm{~A} 2 \mathrm{~b}$ & 30 & 1,639 & 459 & 3.32 & 0.68 \\
\hline 31 & A1 & 21 & 621 & 174 & 3.16 & 0.72 \\
\hline 32 & $\mathrm{~A} 2 \mathrm{~b}$ & 37 & 1,311 & 367 & 4.26 & 0.82 \\
\hline 33 & $\mathrm{~A} 2 \mathrm{~b}$ & 29 & 8,607 & 2,410 & 2.13 & 0.44 \\
\hline 34 & $\mathrm{~A} 2 \mathrm{~b}$ & 19 & 12,229 & 3,424 & 2.20 & 0.52 \\
\hline
\end{tabular}

Cluster group to which each station belongs is also indicated

ysis showed the presence of two major groups of sites at a similarity level of $20 \%$ (Fig. 2): group A (finer sediments) and group B (coarser sediments). Group A was further subdivided into group A1 (St. 23, 27, 28, 31; mud) and group A2 (fine sand), the latter was subdivided into group A2a (St. 8, 9, 20, 21, 22, 24, 25, 26) and A2b (St. 29, 30, $32,33,34$ ). Group B was subdivided in subgroup B1 (St. 13, 14; medium sand) and B2 (St. 2, 3, 6, 7, 12, 17, 18, 19; mostly coarse sand). nMDS ordination showed similar results to those of the dendrogram (Fig. 3). Relative abundance of peracarid orders in each assemblage is shown in Fig. 4.

Group A was located in the sheltered area of the ria. Subgroup A1 was constituted by muddy sites and had lower number of individuals and species than the other subgroups of A. The species that mostly contributed to similarities in A1 were Harpinia pectinata Sars, 1891, Leucothoe incisa and Tanaissus lilljeborgi (Stebbing, 1891), whereas Meta- phoxus simplex Bate, 1857, Harpinia pectinata and Microdeutopus armatus Chevreux, 1887) were the most abundant species. Subgroup A2 was composed of sandy sediments (from muddy sand to coarse sand). The species which mostly contributed to characterize subgroup A2a (mediumfine sand) were Perioculodes longimanus, Leucothoe incisa (present in all stations), Siphonoecetes kroyeranus and Apseudes latreillii, the latter being the most abundant species. Subgroup A2b (fine-muddy sand) was located in the inner part of the ria and showed the highest number of individuals of all groups. This subgroup was characterized by Photis longipes, Microdeutopus versiculatus and Gammarella fucicola, which were present in all stations; those species and Apseudes latreillii were the most abundant.

Group B was located in the outer part of the ria. Subgroup B1 had less total abundance and number of species of peracarids than the other groups of the ría. Subgroup B2 showed the highest number of species of all groups; this subgroup was determined by Guernea coalita, Haplostylus sp. and Eurydice truncata, being Apseudes latreilli the most abundant species.

SIMPER analysis showed that Guernea coalita, Haplostylus sp. and Siphonoecetes kroyeranus explained most of dissimilarity between groups A2a and B2. Guernea coalita, Siphonoecetes kroyeranus and Iphinoe trispinosa (Goodsir, 1843) contributed greatly to the differentiation of B2 from B1. Apseudes latreillii, Siphonoecetes kroyeranus and Lepidepecreum longicornis (Bate and Westwood, 1862) differentiated group A2a from B1. Group A2a differed from A1 due to Harpinia pectinata, Siphonoecetes kroyeranus and Metaphoxus simplex. Gammarella fucicola and Microdeutopus versiculatus differentiated group A2a from A2b, whereas Harpinia pectinata and Microdeutopus versiculatus differentiated group A1 from A2b.

Species affinities

Cluster analysis done on the abundance data of the dominant species showed the existence of three major groups at similarity level of about 15\% (Fig. 5). Group 1 included species mostly found in coarse sand (cluster group B2). Group 2 comprised species found in muddy and fine sand sediments. Subgroup 2a comprised species with higher abundance in muddy sediments (cluster group A1), while subgroup $2 \mathrm{~b}$ was composed of species found in fine sand sediments (cluster group A2b). Group 3 included species mostly found in sediments composed of fine and medium sand (cluster group A2a).

Relation with environmental variables

The BIO-ENV procedure showed that the combination of gravel, very fine sand, silt/clay and depth had the highest 


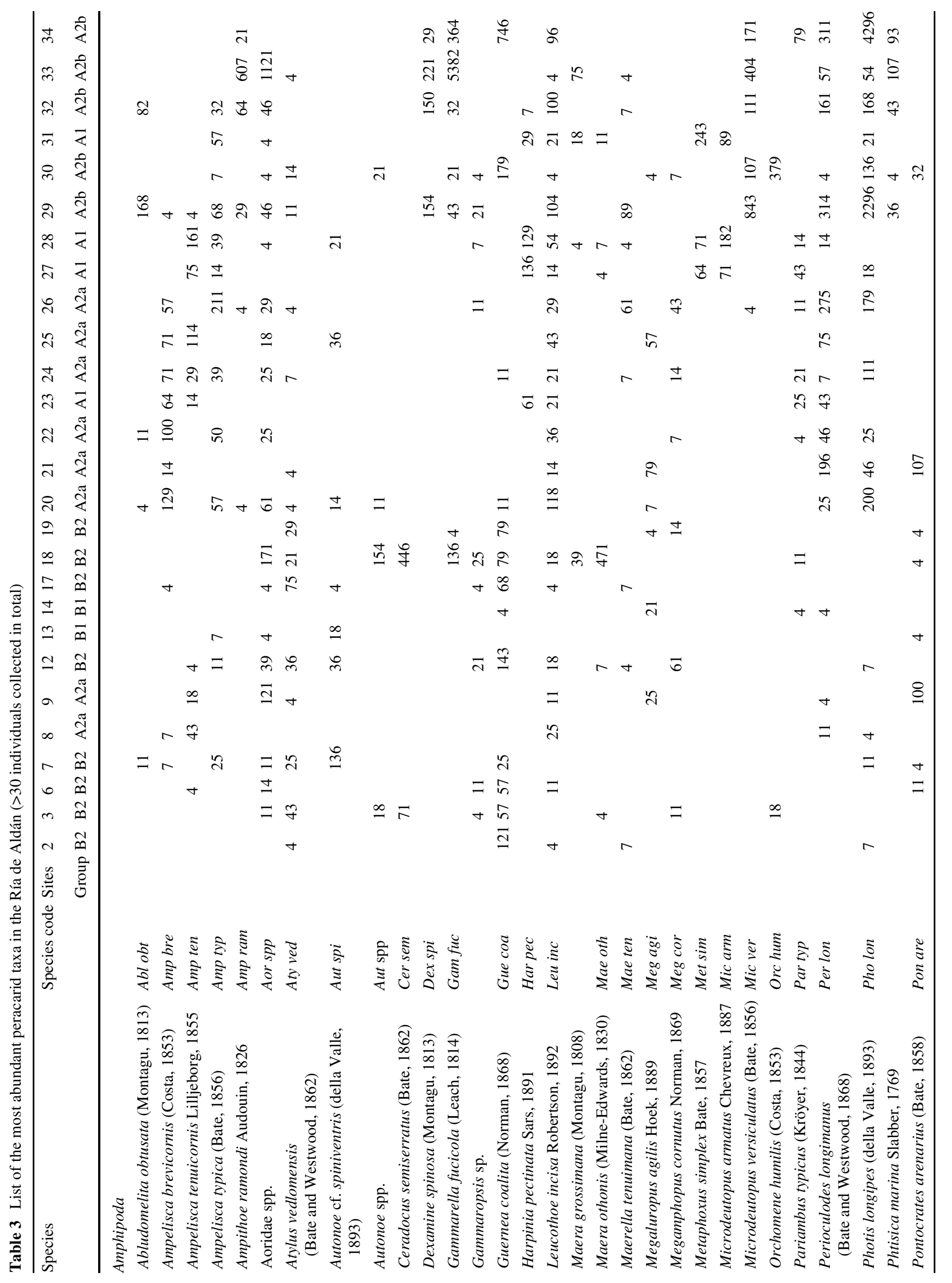




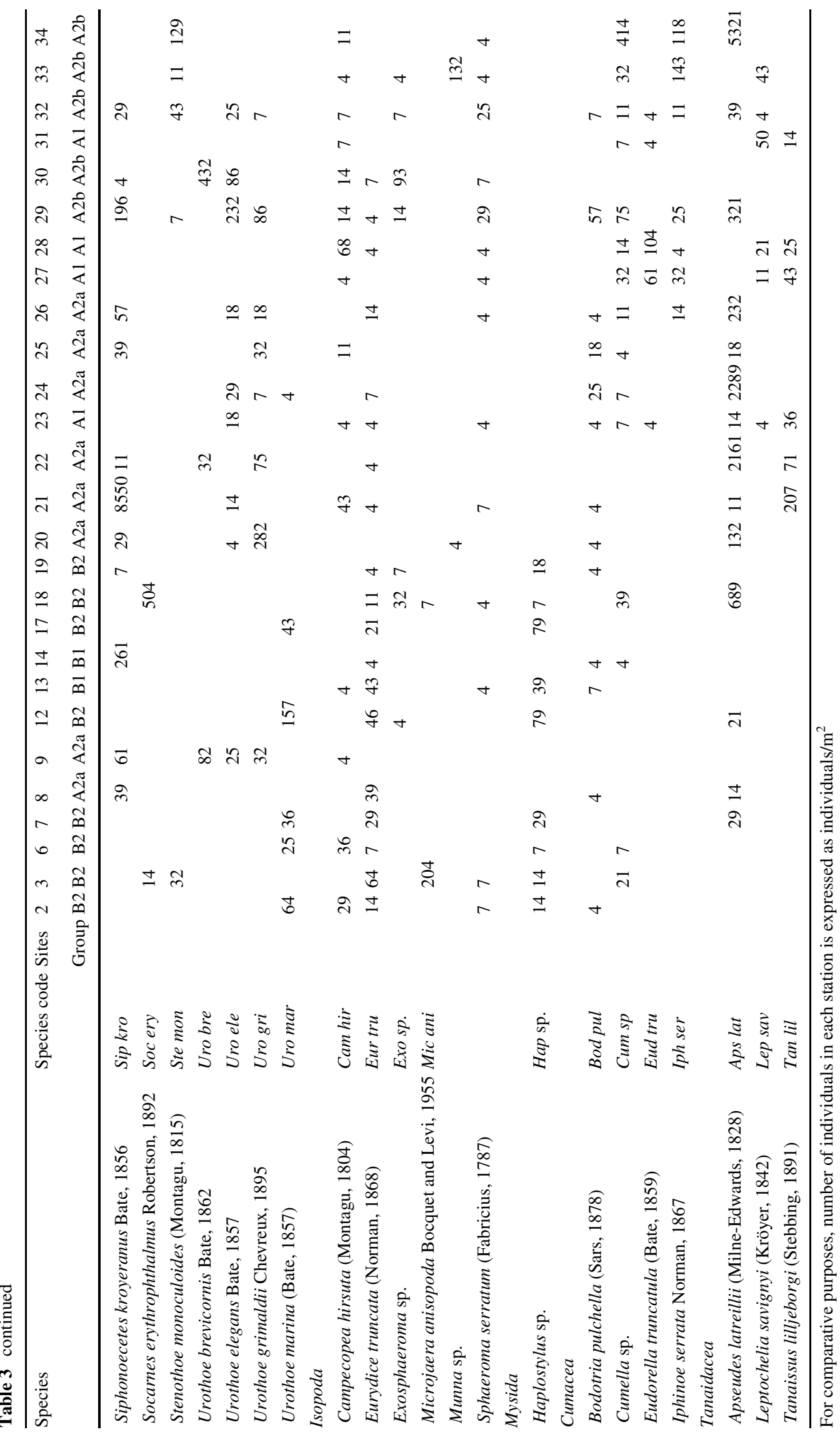




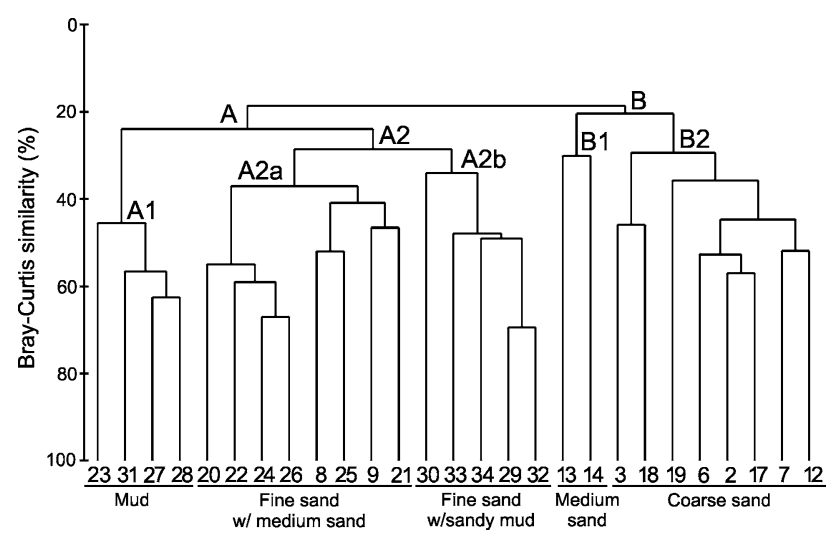

Fig. 2 Peracarid assemblages in the Ría de Aldán as determined by cluster analysis based on Bray-Curtis similarity coefficient

correlation with faunistic data $\left(\rho_{\mathrm{w}} 0.516\right)$. Very fine sand was the variable that alone showed the highest correlation $\left(\rho_{\mathrm{w}} 0.277\right)$, followed by depth $\left(\rho_{\mathrm{w}} 0.270\right)$ and fine sand $\left(\rho_{\mathrm{w}}\right.$ $0.238)$.

The nMDS ordination of sites with superimposed values of the mentioned variables showed that stations appeared distributed from right to left following an increase in very fine sand and fine sand fractions in the sediment, accompanied by decreasing values of depth (Fig. 3).

The forward selection of CCA selected median grain size, silt/clay, sorting coefficient and depth as the variables explaining most of the variance in the species data $(P$ : 0.002). Axes I and II were the most important in the CCA ordination, accumulating $21.2 \%$ of species variance and $27.9 \%$ of species-environment variance. Cluster groups with higher content of coarser granulometric fractions were distributed on the left of the ordination, while assemblages located in fine sand-mud were distributed on the right, following a gradient defined by a decrease in median grain size (Fig. 6).

\section{Discussion}

Peracarid diversity

The peracarid fauna diversity of Ría de Aldán was higher than in other European temperate waters, having been recorded the typical species from shallow sediments of those waters (Dauvin et al. 1994; Conradi et al. 1997; Cunha et al. 1999). The total number of peracarid species founded at Ría de Aldán was 125, while Dauvin et al. (1994) reported 99 peracarid species from the western English channel (circalittoral suprabenthic coarse sand community), Cunha et al. (1999) reported 61 peracarid species from Ría de Aveiro (Portugal), and Conradi and López González (2001) reported 67 peracarid species from Algeciras Bay. Table 4 shows a comparison of the peracarid fauna between the Ría de Aldán and other nearby geographical areas.

The large peracarid diversity at Ría de Aldán was mainly due to the contribution of amphipods (79 species). For example, Garmendia et al. (1998) found 66 amphipod species in Ría de Ares-Betanzos, Conradi et al. (1997), recorded the presence of 53 amphipod species in Algeciras Bay, Parker found 26 subtidal amphipod species in Belfast Lough, Jimeno and Turon (1995) found 71 gammaridean amphipods along the Catalonian coast and Arresti et al.
Fig. 3 nMDS ordination of sampling stations showing groups determined by cluster analysis and ordination of sites with values of some environmental variables superimposed (very fine sand, depth and fine sand)
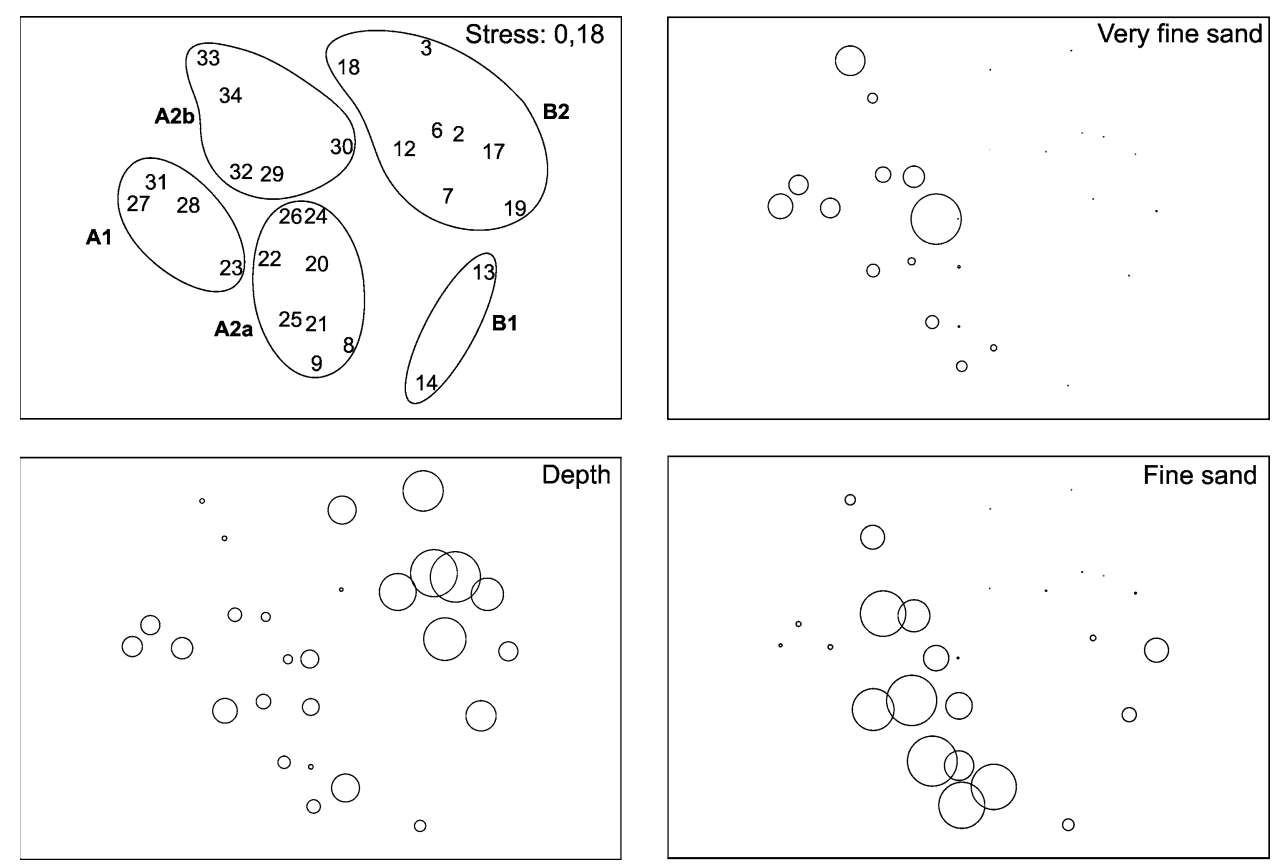

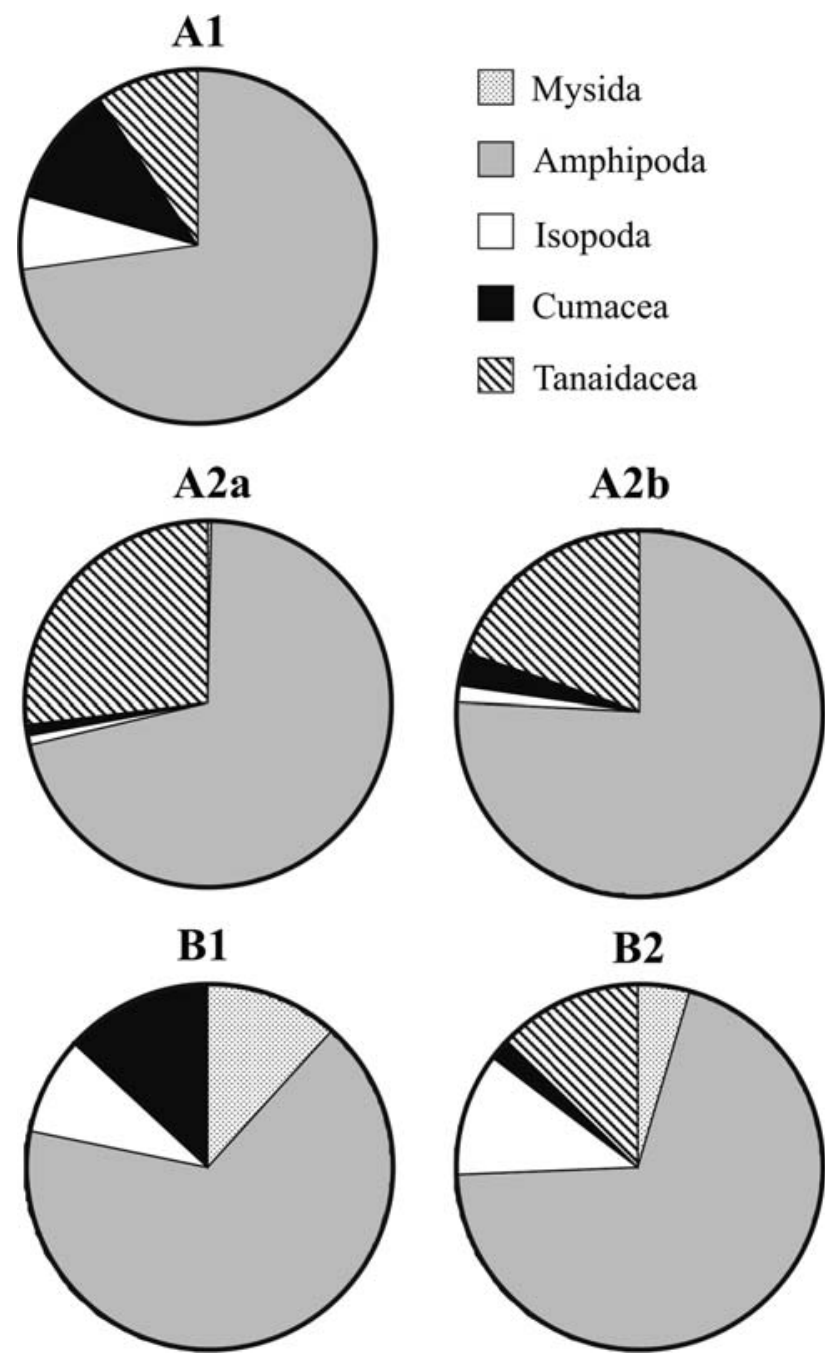

Fig. 4 Relative abundance (\%) of each peracarid order in the groups of stations determined by multivariate analyses

(1986) found 40 amphipod species in the Abra de Bilbao (País Vasco, Spain). Again, this gammaridean diversity was larger than in other similar areas, apart from the English Channel where Dauvin et al. (2000) reported 142 gammaridean amphipods.

Thus, the total number of species of the Ría de Aldán is high enough to consider those soft-bottoms as particularly rich in peracarids. Polychaetes and molluscs also show a high number of species in this ria (Lourido et al. 2006, 2008). This fact may be due to the granulometric heterogeneity existing in this area. Normally, heterogeneous sediments provide many microhabitats which may support a greater biodiversity of species than homogenous sediments do (Gray 1974).

The second peracarid groups in number of species were isopods and cumaceans; whereas, the former was more widespread, the latter was more abundant, both being found from gravel to muddy sediments. Isopods live in most

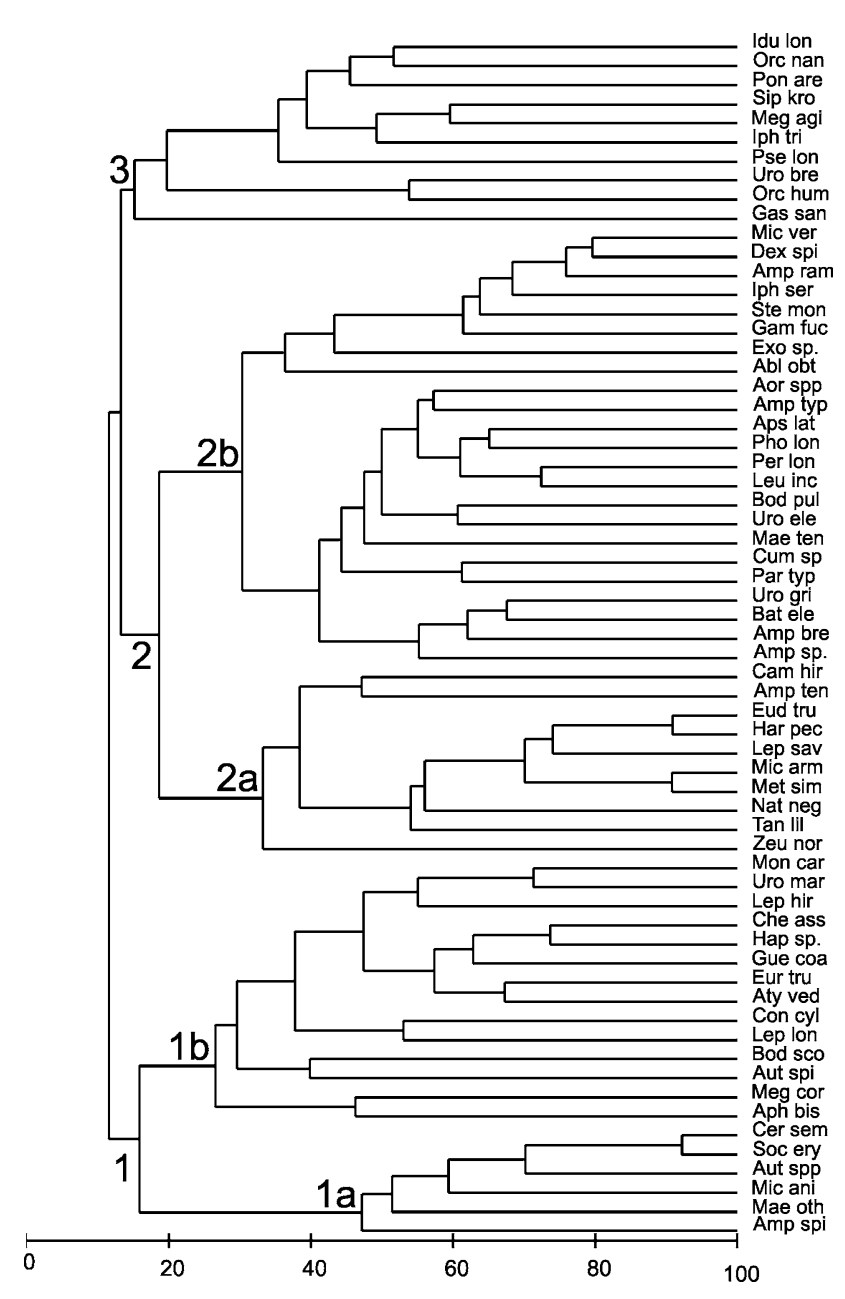

Fig. 5 Dendrogram based on cluster analysis showing the classification of species with a numerical dominance $\geq 4 \%$ at any given site. Species code are given in Table 3, except: Amp sp., Ampelisca sp.; Amp spi, Ampelisca spinipes; Aph bis, Apherusa bispinosa; Bat ele, Bathyporeia elegans; Bod sco, Bodotria scorpioides; Che ass, Cheirocratus assimilis; Con cyl, Conilera cylindracea; Gas san, Gastrosaccus sanctus; Idu lon, Idunella longirostris; Iph tri, Iphinoe trispinosa; Lep hir, Leptocheirus hirsutimanus; Lep lon, Lepidepecreum longicornis; Mon car, Monoculodes carinatus; Nat neg, Natatolana neglecta; Pse lon, Pseudocuma longicorne; Orc nan, Orchomenella nana; Zeu nor, Zeuxo normani

marine habitats, being more diverse in the deep sea (Kensley 1998). Cumaceans can live in all kind of benthic habitats, mud, sand, gravel and on natural rock formations associated with algae or with sessile invertebrates (Alfonso et al. 1998). Nevertheless, other authors state that cumaceans may be more abundant with higher organic matter content and higher proportion of silt/clay in the sediment (Corbera and Cardell 1995).

In the Ría de Aldán, cumaceans showed their highest abundances in muddy sand, being Cumella sp. and Iphinoe serrata Norman, 1867 the most abundant species.

Mysids were poorly represented in our samples. This may happen due to the fact that mysids are sampled more 


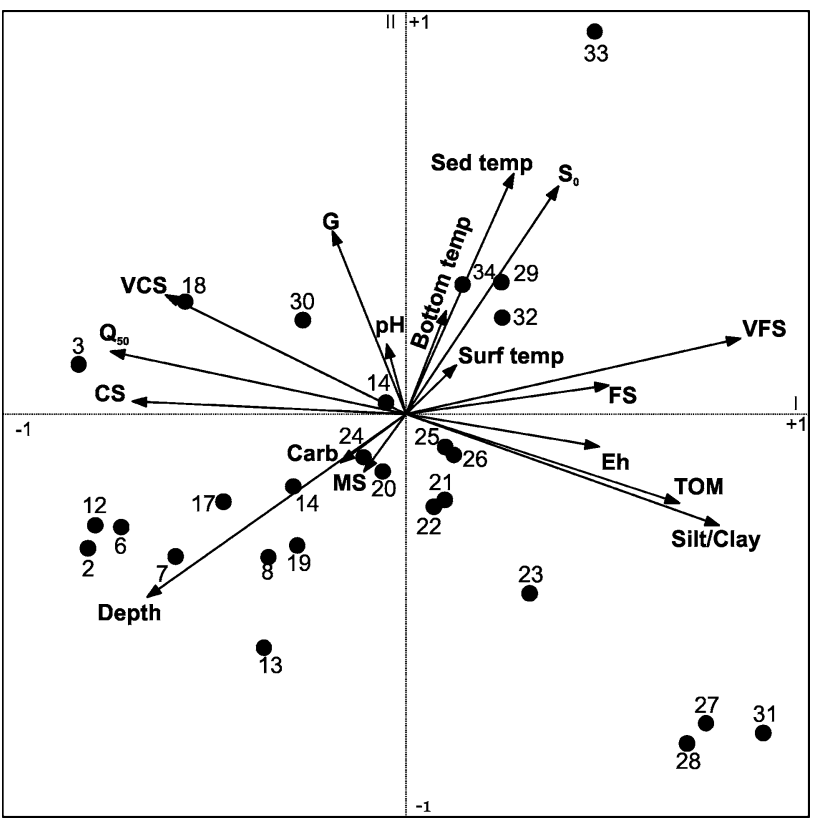

Fig. 6 Canonical correspondence analysis (CCA) ordination of stations and environmental variables relative to axes I and II for the Ría de Aldán. Gravel, G; very coarse sand, VCS; coarse sand, CS; medium sand, MS; fine sand, FS; very fine sand, VFS; median grain size, $\mathrm{Q}_{50}$; sorting coefficient, $\mathrm{S}_{0}$; bottom water temperature, bottom temp; surface water temperature, surf temp; sediment temperature, sed temp; calcium carbonate content, carb; total organic matter content, TOM

efficiently by using epibenthic sledges (Brandt 1995) rather than the grab used here. Tanaids showed a small number of species but a high number of individuals. This fact is due to the numerical dominance of Apseudes latreillii at some stations. Although this species may proliferate in conditions of organic enrichment (Grall and Glémarec 1997), content of organic matter was not high at stations where Apseudes latreillii was dominant. In the Ría de Aldán, this species showed a high number of individuals in different kind of sediments $\left[1,490\right.$ individuals $/ \mathrm{m}^{2}$ in st. 34 (muddy sand), 641 in st. 24 (coarse sand) and 605 in st. 22 (fine sand)].

Peracarid assemblages and environmental conditions

Two major peracarids assemblages were determined in Ría de Aldán through multivariate analyses whose distribution agreed mostly with that of granulometric fractions. Similarly, the distribution of molluscan and polychaete assemblages in the Ría de Aldán also shows the same pattern (Lourido et al. 2006, 2008).

Groups A1 and A2b can be included within the 'Abra alba community' (Petersen 1918). This community has been reported along European coasts in different types of muddy sediments (Glémarec 1964; Cabioch 1968; Gentil et al. 1986; Carpentier et al. 1997) as well as in other Galician rias (Cadée 1968; Olabarría et al. 1998; Moreira et al. 2005). The most abundant peracarids in the muddy sediments of group A1 were Metaphoxus simplex (exclusive), Harpinia pectinata (constant) and Microdeutopus armatus (exclusive). Constant species of this group were Eudorella truncatula (Bate, 1859), Tanaissus lilljeborgi, Leucothoe incisa and Leptochelia savignyi (Kröyer, 1842). In group A2b (muddy sand and fine sand sediment), Photis longipes (constant), Gammarella fucicola (constant) and Apseudes latreillii had a high abundance $\left(>1,500\right.$ individuals $\left./ \mathrm{m}^{2}\right)$. Dexamine spinosa (Montagu, 1813) and Phtisica marina Slabber, 1,769 were constant and exclusive species of this group.

Faunal composition of group A2a (fine sand) can be ascribed to the Venus gallina community (Thorson 1957).

Table 4 Comparison of peracarid diversity between the Ría de Aldán (this work) and other nearby geographical areas (Galicia, Basque country and Portuguese coast)

\begin{tabular}{|c|c|c|c|c|c|c|}
\hline & Amphipoda & Isopoda & Mysida & Cumacea & Tanaidacea & Total \\
\hline Ría de Aldán (Galicia, Spain; this work) & 79 & 20 & 7 & 14 & 5 & 125 \\
\hline Ría de Arousa (Galicia, Spain; López-Jamar 1982) & 7 & 2 & 0 & 1 & 1 & 11 \\
\hline Ría de Ares-Betanzos (Galicia, Spain; Garmendia et al. 1998) & 73 & 9 & 0 & 13 & 2 & 97 \\
\hline Ría de Foz (Galicia, Spain; Junoy and Viéitez 1988) & 12 & 11 & 5 & 2 & 1 & 31 \\
\hline Miño Estuary (Galicia, Spain; Mazé et al. 1993) & 8 & 5 & 1 & 0 & 0 & 14 \\
\hline Panxón (Ría de Vigo, Galicia, Spain; Anadón 1975) & 24 & 8 & 2 & 0 & 0 & 34 \\
\hline Abra de Bilbao (Basque Country, Spain; Arresti et al. 1986) & 40 & 0 & 0 & 0 & 0 & 40 \\
\hline Continental shelf (Basque Country, Spain; Martínez and Adarraga 2001) & 40 & 5 & 3 & 18 & 1 & 67 \\
\hline Hendaya beach (Basque Country, Spain; San Vicente and Sorbe 2001) & 19 & 3 & 12 & 5 & 0 & 39 \\
\hline Western Portuguese coast (Sousa Reis et al. 1982) & 20 & 8 & 5 & 5 & 0 & 38 \\
\hline Albufeira and Obidos lagoons (Portugal; Rodrigues and Dauvin 1985) & 36 & 0 & 5 & 4 & 0 & 45 \\
\hline Mondego Estuary (Portugal; Marques et al. 1993) & 18 & 10 & 1 & 0 & 0 & 29 \\
\hline Ovar Channel (Ría de Aveiro, Portugal; Cunha et al. 1999) & 26 & 6 & 9 & 1 & 2 & 44 \\
\hline Mira Channel (Ría de Aveiro, Portugal; Cunha et al. 1999) & 30 & 9 & 12 & 3 & 2 & 56 \\
\hline
\end{tabular}


In this community, Siphonoecetes kroyeranus (constant) and Apseudes latreillii (constant) were the most abundant species. Furthermore, Bathyporeia elegans Watkin, 1938 was constant and exclusive, Ampelisca sp. exclusive and Perioculodes longimanus, Ampelisca brevicornis (Costa, 1853) and Leucothoe incisa were constant.

The most abundant peracarid in group B1 (medium sand) was the amphipod Siphonoecetes kroyeranus. The characteristic species were Eurydice truncata, Iphinoe trispinosa, Lepidepecreum longicornis and Pseudocuma longicorne (Bate, 1858) (all constant) and the amphipod Leucothoe spinicarpa (Abildgaard, 1789) (exclusive). The mysid Gastrosaccus spinifer (Goës, 1864) (constant and elective) was also a typical species of this kind of sediment.

The coarse sandy sediments of group B2 has a fauna that could be included among the different varieties of the 'Branchiostoma lanceolatum-Venus fasciata community' (Thorson 1957). Several authors have reported the presence of similar faunal associations in other areas of Galicia such as the Ría da Coruña (López-Jamar and Mejuto 1985), the Ría de Ares-Betanzos (Troncoso et al. 1993, 2005) and the Ensenada de Baiona (Moreira et al. 2005), and in other areas outside of Galicia, such as the Baie de Morlaix in the Manche Occidental (Dauvin 1988b).

Apseudes latreillii was the most abundant peracarid of this group. Guernea coalita, Haplostylus sp. and Atylus vedlomensis were constant species, while Socarnes erythrophthalmus Robertson, 1892 and Ceradocus semiserratus (Bate, 1862) and Ampelisca spinipes Boeck, 1861 were exclusive.

Among factors determining distribution of peracarids and composition of assemblages in sediments are temperature, stability of substrate, grain size, organic matter content, food availability, burrowing ability, the role of pollutants and diel activity changes determined by specific behavioural patterns (endogenous rhythms, predation, etc.) (Corbera and Cardell 1995; Weisshappel and Svavarsson 1998; Cunha et al. 1999). Grain size is, however, one of the most often reported (Robertson et al. 1989).

Our results suggest that sedimentary composition and a number of environmental gradients existing in the ria related to depth such as hydrodynamism, sedimentation, carbonates, organic matter and the presence of seaweeds are the major factors controlling peracarid spatial distribution. The number of species tended to be higher in fine sand and coarse sand assemblages than in muddy sediments. Similarly, Biernbaum (1979) reported higher number of species in coarse sand and Dauvin et al. (1994) found a high peracarid diversity in circalittoral coarse sands from the English channel. In the Ría de Aldán, total number of individuals is higher in muddy sand sediments than in other sediments. This fact can be due to the great variety of habitats present in sampling stations close to the river mouth which are, in addition, colonized by a number seaweeds. The presence of seaweeds increases the number of microhabitats and there are more ecological niches. Furthermore, seaweeds contribute to stabilize the sediment, food availability is greater than in naked sediments, and seaweeds give protection against a number of predators.

Acknowledgments The authors want to express their gratitude to laboratory colleagues for their invaluable help with many tasks, including sample collection and Dr Jean Claude Sorbe (Station Marine d'Arcachon) for his help in identification of the peracarid taxa reported in this paper. Two anonymous referees provided valuable comments which contributed to improve earlier versions of the manuscript. This study was a part of $\mathrm{PhD}$ (A.L.) supported by a FPU scholarship of the Spanish Ministry of Education and Science Ministry.

\section{References}

Alfonso MI, Bandera ME, López-González PJ, García-Gómez JC (1998) The cumacean community associated with a seaweed as a bioindicator of environmental conditions in the Algeciras Bay (Strait of Gibraltar). Cahiers de Biologie Marine 39:197-205

Anadón R (1975) Aportación al conocimiento de la fauna bentónica de la ría de Vigo (NW de España) I. Pycnogónidos y crustáceos de Panjón. Investigaciones Pesqueras 39:199-218

Arresti A, Iturrondobeitia JC, Rallo A (1986) Contribución al conocimiento faunístico y ecológico del orden Amphipoda en el Abra de Bilbao (C. Vasca). Cuadernos de Investigación Biológica (Bilbao) 9:89-125

Beare DJ, Moore PG (1996) The distribution, growth and reproduction of Pontocrates arenarius and P. altamarinus (Crustacea: Amphipoda) at Millport, Scotland. J Mar Biol Assoc UK 76:931-950

Biernbaum CK (1979) Influence of sedimentary factors on the distribution of benthic amphipods of Fishers Island Sound, Connecticut. J Exp Mar Biol Ecol 38:201-223

Brandt A (1995) Peracarid fauna (Crustacea, Malacostraca) of the Northeast Water Polynya off Greenland: documenting close benthic-pelagic coupling in the Westwind Trough. Mar Ecol Prog Ser 121:39-51

Cabioch L (1968) Contribution a la connaissance des peuplements benthiques de la Manche occidentale. Cahiers de Biologie Marine 9:493-720

Cadée GC (1968) Molluscan biocoenoses and thanatocoenoses in the Ría de Arosa, Galicia. Zoologische Verhandelingen 95:1-121

Carpentier P, Dewarumez JM, Leprêtre A (1997) Long-term variability of the Abra alba community in the southern bight of the North Sea. Oceanol Acta 20:283-290

Clarke KR, Warwick RM (1994) Changes in marine communities: an approach to statistical analyses and interpretation. Natural Environment Research Council, UK

Conradi M, López-González PJ, García-Gómez JC (1997) The amphipod community as a bioindicator in Algeciras Bay (Southern Iberian Peninsula) based on a spatio-temporal distribution. Mar Ecol 18:97-111

Conradi M, López González PJ (2001) Relationships between environmental variables and the abundance of peracarid fauna in Algeciras Bay (Southern Iberian Peninsula). Ciencias Marinas 27:481500

Corbera J, Cardell MJ (1995) Cumaceans as indicators of eutrophication on soft bottoms. Scientia Marina 59(Suppl 1):63-69

Cunha MR, Sorbe JC, Moreira MH (1999) Spatial and seasonal changes of brackish peracaridan assemblages and their relation to some 
environmental variables in two tidal channels of the Ria de Aveiro (NW Portugal). Mar Ecol Prog Ser 190:69-87

Currás A, Mora J (1991) Comunidades bentónicas de la Ría del Eo (Galicia-Asturias, NW España). Cahiers de Biologie Marine 32:57-81

Dauvin J-C (1988a) Rôle du macrobenthos dans l'alimentation des Poissons démersaux vivant sur les fonds de sédiments fins de la Manche occidentale. Cahiers de Biologie Marine 29:445-467

Dauvin J-C (1988b) Structure et organisation trophique du peuplement des sables grossiers á Amphioxus lanceolatus-Venus fasciata de la baie de Morlaix (Manche Occidental). Cahiers de Biologie Marine 29:163-185

Dauvin J-C, Iglesias A, Lorgeré JC (1994) Circalittoral suprabenthic coarse sand community from the Western English Channel. J Mar Biol Assoc UK 74:543-562

Dauvin J-C, Vallet C, Zouhiri S, Mouny P (2000) Main characteristics of the Boundary Layer Macrofauna in the English Channel. Hydrobiologia 426:139-156

De Grave S (1999) The influence of sedimentary heterogeneity on within maerl bed differences in infaunal crustacean community. Estuar Coast Shelf Sci 49:153-163

Duffy JE, Hay ME (2000) Strong impacts of grazing amphipods on the organization of a benthic community. Ecol Monogr 70:237-263

Field JG, Clarke KR, Warwick RM (1982) A practical strategy for analysing multispecies distribution patterns. Mar Ecol Prog Ser 8:37-52

Figueiras FG, Labarta U, Fernández MJ (2002) Coastal upwelling, primary production and mussel growth in the Rias Baixas of Galicia. Hydrobiologia 484:121-131

Fincham AA (1974) Intertidal sand-dwelling peracarid fauna of Stewart Island New Zealand. J Mar Freshw Res 8:1-14

Garmendia JM, Sánchez-Mata A, Mora J (1998) Inventario de la macrofauna bentónica de sustratos blandos submareales de la Ría de Ares y Betanzos (NO de la Península Ibérica). Nova Acta Científica Compostelana (Bioloxía) 8:209-231

Gentil F, Irlinger JP, Elkaim B, Proniewski F (1986) Prémieres données sur la dynamique du peuplement macrobenthique des sables fins envasés á Abra alba de la Baie de Seine orientale. Actes de Colleques. IFREMER 4:409-420

Glémarec M (1964) Bionomie benthique de la partie orientale du Golfe de Morbihan. Cahiers de Biologie Marine 5:33-96

Gómez-Gesteira JL, Dauvin J-C (2000) Amphipods are good bioindicators of the impact of oil spills on soft-bottom macrobenthic communities. Mar Pollut Bull 40:1017-1027

Grall J, Glémarec M (1997) Using biotic indices to estimate macrobenthic community perturbations in the Bay of Brest. Estuar Coast Shelf Sci 44(Suppl A):43-53

Gray JS (1974) Animal-sediment relationships. Oceanography Mar Biol: an Annu rev 12:223-261

Guerra-García JM, García-Gómez JC (2004) Crustacean assemblages and sediment pollution in an exceptional case study: a harbour with two opposing entrances. Crustaceana 77:353-370

Jimeno A, Turon X (1995) Gammaridea and Caprellidea of the northeast coast of Spain: ecological distribution on different types of substrata. Polskie Archiwum Hydrobiologii 42:495-516

Junoy J, Viéitez JM (1988) Crustáceos intermareales de sustrato blando de la Ría de Foz (Lugo). Actas III Congreso Ibérico de Entomología 529-540

Junoy J, Viéitez JM (1989) Cartografía de los sedimentos superficiales de la Ría de Foz (Lugo). Thalassas 7:9-19

Junoy J (1996) La Ría de Foz, comunidades bentónicas. Servicio de Publicaciones de la Diputación Provincial de Lugo, Spain

Kensley B (1998) Estimates of species diversity of free-living marine isopod crustaceans on coral reefs. coral reefs 17:83-88

López-Jamar E (1982) Distribución espacial de las comunidades bentónicas infaunales de la Ría de Arosa. Boletín del Instituto Español de Oceanografía 7:255-268
López-Jamar E, Mejuto J (1985) Bentos infaunal en la zona submareal de la ría de La Coruña I. Estructura y distribución espacial de las comunidades. Boletín del Instituto Español de Oceanografía 2:99-109

Lourido A, Gestoso L, Troncoso JS (2006) Assemblages of the molluscan fauna in subtidal soft bottoms of the Ría de Aldán (northwestern Spain). J Mar Biol Assoc UK 86:129-140

Lourido A, Cacabelos E, Troncoso JS (2008) Patterns of distribution of the polychaete fauna in subtidal soft bottoms of the Ría de Aldán (north-western Spain). J Mar Biol Assoc UK 88:263-275

Marques JC, Bellan-Santini D (1990) Benthic amphipod fauna (Crustacea) of the Portuguese coast: Biogeographical considerations. Mar Nat 3:43-51

Marques JC, Rodrigues LB, Nogueira AJA (1993) Intertidal macrobenthic communities structure in the Mondego Estuary (Western Portugal): Reference situation Vie Milieu 43(2/3):177-187

Martínez J, Adarraga I (2001) Distribución batimétrica de comunidades macrobentónicas de sustrato blando en la plataforma continental de Guipúzcoa (golfo de Vizcaya). Boletín del Instituto Español de Oceanografía 17:33-48

Mazé RA, Laborda AJ, Luis E (1990) Macrofauna intermareal de sustrato arenoso en la Ría de El Barquero (Lugo, NO de España). IIEstructura de la comunidad. Zonación. Cahiers de Biologie Marine 31:47-64

Mazé RA, Lastra M, Mora J (1993) Macrozoobentos del Estuario del Miño (NO de España). Publicaciones Especiales. Instituto Español de Oceanografía 11:283-290

McDermott JJ (1987) The distribution and food habits of Nephtys bucera Ehlers, 1868 (Polychaeta; Nephtyidae) in the surf zone of a sandy beach. Proc Biol Soc Washington 100:21-27

Moreira J, Quintas P, Troncoso J S (2005) Distribution of the molluscan fauna in the subtidal soft bottoms of the Ensenada de Baiona (NW Spain). Am Malacol Bull 20:75-86

Nombela MA, Vilas F, Evans G (1995) Sedimentation in the mesotidal Rías Bajas of Galicia (north-western Spain): Ensenada de San Simón Inner Ría de Vigo. Spec Publ Int Assoc Sedimentologists 24:133-149

Olabarría C, Urgorri V, Troncoso JS (1998) An analysis of the community structure of subtidal and intertidal benthic mollusks of the Inlet of Baño (Ría de Ferrol) (northwest Spain). Am Malacol Bull 14:103-120

Palacio J, Lastra M, Mora J (1991) Distribución vertical de la macrofauna intermareal de la Ensenada de Lourizán (Ría de Pontevedra). Thalassas 9:49-62

Parada J (2004) Cartografía biosedimentaria y comunidades bentónicas de los fondos blandos submareales de las Rías de Pontevedra y Aldán y la Ensenada de A Lanzada. PhD thesis. Universidad de Santiago de Compostela, Galicia, Spain

Parker JG (1984) The distribution of the subtidal Amphipoda in Belfast Lough in relation to sediment types. Ophelia 23:119-140

Petersen CGJ (1918) The sea-bottom and its production of fish-food. A survey of the work done in connection with the valuation of the Danish waters from 1883-1917. Rep Danish Station Biol 25:1-62

Prato E, Biandiolino F (2005) Amphipod biodiversity of shallow water in the Taranto seas (north-western Ionian Sea). J Mar Biol Assoc UK 85:333-338

Robertson MR, Hall SJ, Eleftheriou A (1989) Environmental correlates with amphipod distribution in a Scottish sea loch. Cahiers de Biologie Marine 30:243-258

Rodrigues AM, Dauvin J-C (1985) Crustacés Amphipodes des sédiments meubles subtidaux des lagunes d'Albufeira et Obidos (Portugal). Péracarides (Amphipodes, Cumacés et Mysidacés) de la zone cotière de la lagune d'Obidos. Ciênc Biol Ecol Syst (Portugal) 5:251-267

San Vicente C, Sorbe JC (2001) Temporal changes in the structure of the suprabenthic community from Hendaya beach (southern Bay 
of Biscay): a comparison with a northwestern mediterranean beach community. Boletín del Instituto Español de Oceanografía 17:107-120

Sánchez-Mata A, Lastra M, Mora J (1993) Macrobenthic crustacean assemblages characterization of an estuarine area. Crustaceana 64:338-355

Sousa Reis C, Monteiro Marques V, Calvário J, Marques JC, Melo R, Santos R (1982) Contribuição para o estudo dos povoamentos bentónicos (substrato móvel) da costa ocidental portuguesa. Oecologia aquatica 6:91-105

Ter Braak C (1988) Canoco-a Fortran program for the canonical community ordination by partial, detrended, canonical correspondence analysis, principal components analysis and redundancy analysis. Agricultural Mathematics Group, Ministry of Agriculture and Fisheries, Ithaca, New York, 95 pp

Thorson G (1957) Bottom communities (Sublittoral or Shallow Shelf). Memoires of the Geological Society of America 67:461-534
Trask PD (1932) Origin and environment of source sediments of petroleum. Houston Gulf Publications Co., Houston

Troncoso JS, Urgorri V, Parapar J (1993) Cartografía de los moluscos infralitorales de sustratos blandos de la Ría de Ares y Betanzos (Galicia, NO de España). Publicaciones Especiales del Instituto Español de Oceanografía 11:131-137

Troncoso JS, Moreira J, Urgorri V (2005) Soft-bottom mollusc assemblages in the Ría de Ares-Betanzos (Galicia, NW Spain). Iberus 23:25-38

Viéitez JM, Baz A (1988) Comunidades bentónicas de sustrato blando intermareal de la Playa de Lapamán (Ría de Pontevedra, Galicia). Cahiers de Biologie Marine 29:261-276

Weisshappel JBF, Svavarsson J (1998) Benthic amphipods (Crustacea: Malacostraca) in Iceland waters: diversity in relation to faunal patterns from shallow to intermediate deep Arctic and North Atlantic Oceans. Mar Biol 131:133-143 